IJM

43,9

42

Received 8 December 2020

Revised 17 May 2021

3 September 2021

Accepted 8 October 2021

\section{Gender pay gap in explaining female entrepreneurship - industry perspective of selected European countries}

\author{
Aleksandra Gaweł and Katarzyna Mroczek-Dąbrowska \\ Poznan Univeristy of Economics and Business, Poznan, Poland
}

\begin{abstract}
Purpose - Although several theoretical concepts imply different determinants of female entrepreneurship, the literature lacks a consensus on their significance. The aim of this paper is to verify how industry specificity influences the gender pay gap and its relation to female entrepreneurship.

Design/methodology/approach - The authors distinguish industries based on the gender equality level, measured jointly by two factors: pay gap level and female participation rate. The study has been conducted among 22 European countries with relatively similar institutional backgrounds. The authors carry out the analysis based on the panel regression models, which enable the authors to verify two predefined research questions.

Findings - The results of panel regression models indicate that industry specificity plays a significant role in the relation between the pay gap and female entrepreneurship. Generally, it can be concluded that gender pay gap as a measure of gender inequality is dependent on the industry specificity. The dependence is especially visible in the breakdown of male- and female-dominated industries.

Originality/value - The findings are consistent with the assumption that the gender pay gap is a discriminatory factor for women willing to become entrepreneurs in certain industries. The findings of the study may constitute a vital tool in planning to overcome it.
\end{abstract}

Keywords Female entrepreneurship, Gender pay gap, Entry discrimination

Paper type Research paper

\section{Introduction}

The gender gap in entrepreneurship is noticeable across the countries and over time as among entrepreneurs in European countries, on average, one-third are women and two-third are men. However, the female entrepreneurship rates differ depending on the industry, i.e. in some industries such as for example ICT or construction, women account for less than $20 \%$ of entrepreneurs, while in others, for instance in education or health care, even the reversed gender gap can be observed as females constitute about $60 \%$ of entrepreneurs.

Female entrepreneurship can be explained by several theories, including the occupational choice theory with push and pull motivation concepts. According to occupational choice theory, a person who makes occupational choice has two alternative options: to become an employee or to become an entrepreneur (Kihlstrom and Laffont, 1979; Dawson et al., 2014; Fitzpatrick, 2017; Pardo and Ruiz-Tagle, 2017). Rationally, a person makes the optimal decision, comparing the expected costs and benefits of both forms, assuming that entrepreneur receives a risky entrepreneurial profit while an employee a risk-free salary.

\section{JEL Classification — L26, J16, J31}

(C) Aleksandra Gaweł and Katarzyna Mroczek-Dąbrowska. Published by Emerald Publishing International Journal of Manpower Vol. 43 No. 9,2022 pp. $42-59$ Emerald Publishing Limited $0143-7720$ DOI 10.1108/IJM-12-2020-0554
Limited. This article is published under the Creative Commons Attribution (CC BY 4.0) licence. Anyone may reproduce, distribute, translate and create derivative works of this article (for both commercial and non-commercial purposes), subject to full attribution to the original publication and authors. The full terms of this licence may be seen at http://creativecommons.org/licences/by/4.0/legalcode 
This decision is determined by several factors, including positive ones, for example, psychological factors related to proactive and independent personality, access to financial capital or existence of market opportunities; and negative factors, for example, unemployment or unsatisfying work.

The gender pay gap, according to which women receive lower pay than men for the same work, is observed and has so far been widely analyzed in the literature (Khoreva, 2011; Lips, 2013; Arrazola and de Hevia, 2016; Ravazzini and Chesters, 2018). The gender pay gap is explained by the human capital theory, which seeks its roots in differences in male and female experiences, education, skills, etc., and discriminatory preferences (Barnet-Verzat and Wolff, 2008; Cutillo and Centra, 2017; Tverdostup and Paas, 2017); by institutional theory (Munir Sidani, 2013; Reichborn-Kjennerud and Svare, 2014) or by heterodox theory (Karamessini and Ioakimoglou, 2007). Another perspective on the gender pay gap is covered by the labor market segmentation theory, which indicates that women are pushed to enter the secondary labor market with lower productivity and wages (Bauder, 2001; Karamessini and Ioakimoglou, 2007; Munir Sidani, 2013; Kovalenko and Mortelmans, 2014; Aidis and Weeks, 2016).

If we adopt the occupational choice theory perspective, labor market discrimination against women should become a factor pushing women toward entrepreneurship. However, some research posits that entrepreneurship can be a glass cage for women, as the gender pay gap of entrepreneurial earnings is even higher than the gap in wages (Lawter et al., 2016). That in turn might make pay gap a discrimination barrier for entrepreneurial entry. Bearing in mind these interdependencies, we are thus lead to ask questions about the impact of the gender pay gap on female entrepreneurship in the context of industry segmentation. Industries and their characteristics seem therefore to play a vital role in explaining whether and how the gender pay gap influences the occupational choice.

Hence, to understand the problem, industry perspective is adopted. Industries are classified based on two aspects: the level of the gender pay gap and the level of female participation in employment, which reflects labor market discrimination in relation to earnings discrepancies and the issue of occupational segregation. This attitude lets us create a theoretical matrix of industries based on level of pay gap and level of female participation. This classification is the result of two sets of discrimination factors: pay discrimination and industry entry discrimination. Specifically, following research questions are considered in the paper:

$R Q 1$. Does the gender pay gap impact female entrepreneurship in individual industries?

$R Q 2$. What is the nature of the gender pay gap's impact on female entrepreneurship? Is it a pushing or discouraging factor?

RQ3. Are there significant differences in the impact of the gender pay gap on female entrepreneurship in industries with different levels of gender pay gap?

RQ4. Does the female participation rate in a given industry moderate the impact of gender pay gap on the female entrepreneurship?

RQ5. Are there significant differences in the impact of the gender pay gap on female entrepreneurship in male-dominated and female-dominated industries?

The overall aim of the paper is to explore the relationships between the female entrepreneurship and gender pay gap in industry breakdown. We seek factors, other than pay gap, that might influence the occupational choices of women in chosen industries. The research was conducted among European countries (as their level of equality is relatively high), based on yearly panel data for the time span of 2009-2018. From our initial data set, industries or countries with too few observations were rejected, and the final study sample encompasses 12 industries and 22 countries. 
IJM

43,9

Results show that the influence of the gender pay gap on female entrepreneurship strongly depends on the characteristics of industry and its equality level. The gender pay gap is a factor that negatively influences female entrepreneurship in industries with a high level of gender inequality, measured by a low level of female participation and a high level of pay gap. In industries with a relatively high female participation rate, the gender pay gap is not statistically significant in explaining female entrepreneurship; other factors, accepted in the research as control variables, shape female entry to entrepreneurship. Altogether, it can indicate that the gender pay gap should be rather treated as a measure or a symbol of discrimination which discourages women to enter into entrepreneurship in highly unequal industries rather than as a factor pushing them toward such a path. It gives support for institutional theories explaining female entrepreneurship rather than neoclassical ones.

\section{Literature review}

Gender pay gap - theoretical introduction

Although modern societies increase the level of gender equality by increasing women's participation in the workforce and men's contribution in domestic work (Alsos et al., 2016), the gender gap in income and wealth is well established (Ravazzini and Chesters, 2018; Lips, 2013; Khoreva, 2011). Equal pay for work of equal value is a key value of modern societies (Amado et al., 2018), and although the gender pay gap is empirically still observed, however, it has declined considerably in recent years with important gender differences in occupation and industry (Blau and Kahn, 2017). The gender difference is recognized not only through observed wages but also through offered wages, and importantly, the pay gap is even higher among offered wages than observed ones (Arrazola and de Hevia, 2016). Another aspect is the existence of the perceived gender pay gap as the result of the way individuals compare their wages among themselves (Khoreva, 2011). The gender pay gap is also important as it impacts poverty levels (Gradín et al., 2010).

The most widely used method to measure the gender pay gap is based on the decomposition approach. Male and female wages are estimated separately and decomposed into two parts: the part that is explained by the worker's productivity and the unexplainable part, which constitutes evidence of gender discrimination (Amado et al., 2018). The explanations of the gender wage gap can be analyzed at two levels: at the macro level, which perceives women as a homogeneous group and analyzes such factors as education, work experience or types of discrimination; and at the micro level, where women are treated as a heterogeneous group with personal factors, i.e. individual preferences or attitudes (Khoreva, 2011).

Since the late 1950s, economists have theorized about gender differences in wages within neoclassical, institutional and radical tracks (Karamessini and Ioakimoglou, 2007). The neoclassical tradition is reflected in the human capital models, where there are three main factors influencing gender differences in the labor market: preferences, productivity and discrimination (Cutillo and Centra, 2017). The human capital theory assumes that gender pay differences are explained by such tangible inputs as education and accumulated experience. The wage gap reflects different educational backgrounds, shorter tenures and women's interrupted careers (Jamali et al., 2008). Results show some male-specific abilities, such as, for example, problem-solving in a technology-rich environment, which are not always common among women (Tverdostup and Paas, 2017). The observed convergence of women and men education and experience as human capital factors explain the narrowing of gender pay gap as women generally exceeded men in their educational attainment and improved their working experience (Blau and Kahn, 2017).

The gender pay gap can also be the result of preentry discrimination, which influences the average accumulation of human capital by men and women (Karamessini and Ioakimoglou, 2007). The labor market segmentation theory, which challenges the human capital theory 
(Bauder, 2001), assumes that the labor market is divided into two parts, known as the primary and secondary labor markets, with different job characteristics such as wage structure, sector or industry, job autonomy and complexity, opportunities of development (Kovalenko and Mortelmans, 2014). More developed models of labor market segmentation assume tripartite, quadruple and hierarchical segmentation (Bauder, 2001). Occupational segregation leads to situations where men concentrate in primary sectors or segments, while women concentrate in secondary ones (Karamessini and Ioakimoglou, 2007; Jamali et al., 2008). Women tend to work in sectors, industries, occupations and jobs with lower labor productivity, which results in the increase of the gender gap (Aidis and Weeks, 2016). One of the main ideas of this theory is that the boundaries between segments are rigid and protected against individuals moving freely between segments (Bauder, 2001). Female occupational choices often result from their limited possibilities and domestic responsibilities (Cutillo and Centra, 2017). Female-typed jobs are often remunerated by a lower wage than other male-dominated jobs (Munir Sidani, 2013). Women are more likely to appreciate job security and employment benefits, while the pay grade is a more important factor for men (Cutillo and Centra, 2017).

However, critics of the human capital concept indicate that the situation is far more complex, since causal influences work in both directions, i.e. variables associated with the pay gap alone cannot explain the social and cultural context (Lips, 2013). Research results indicate that gender wage differences are explained not by factors related to human capital but by social, institutional and cultural factors, as well as discrimination against women (Arrazola and de Hevia, 2016). Other research indicates that it is caused by differences in labor market characteristics rather than differences in their rewards (Barnet-Verzat and Wolff, 2008).

Among heterodox theories on labor market, the feminist theory contributes by adding the perspective of occupational segregation as the outcome of the gendered socialization processes. Constraints in the employment options available for women impact female human capital investment, occupational choices and access to low-pay and low-status jobs (Karamessini and Ioakimoglou, 2007).

Other explanations of the gender pay gap are connected to models of the "glass ceiling" and "glass (sticky) floor". The "glass ceiling" is related to gap acceleration in the upper tail of wage distribution, which prevents women from achieving higher wages. The wage gap larger at the bottom of distribution - is interpreted as a "glass floor" (Barnet-Verzat and Wolff, 2008; Tverdostup and Paas, 2017) or "sticky floor" (Xiu and Gunderson, 2014).

Another explanation of pay gap results from the institutional theory, which shows how institutions reflect, structure and reinforce gendered patterns of power, which in turn influence the career choices made by men and women (Reichborn-Kjennerud and Svare, 2014). The institutional theory explains market interactions and behaviors from the point of view of formal (i.e. regulations, procedures, education, family context and differential of income level) and informal (i.e. networks, culture, values, beliefs) institutions (Estrin and Mickiewicz, 2011) or divide institutions into three pillars: regulative pillar (codified rules and laws), the normative pillar (beliefs, norms or standards of behavior) and the cultural-cognitive pillar (culture, customs and traditions) (Naguib and Jamali, 2015). Among cultural factors, the gender pay gap depends on gender egalitarianism and institutional collectivism (Munir Sidani, 2013).

An unfavorable and unequal situation for women in the labor market, from neoclassical point of view, should be a factor pushing them toward entrepreneurship. By running their own businesses, women could be rewarded based on their productivity and not based on discrimination. The question whether entrepreneurship could be an escape from gender inequality is not a new one, as indicated, for instance, by Bourne (2010). It goes in line with emancipation perspective which treats entrepreneurship as a freedom from existing constrains (Jennings et al., 2016). Still, the existing data show a considerable gender gap in entrepreneurial activity worldwide, with significantly more men than women starting or operating new businesses (Langevang et al., 2015). 
IJM

43,9

Female entrepreneurship from a theoretical point of view

Female entrepreneurship has been a subject of increasing interest since the early 1980s ( $\mathrm{Ng}$ and $\mathrm{Fu}, 2018)$ as men are more likely to enter into entrepreneurship to create and grow their own businesses (Rubio-Banón and Esteban-Lloret, 2016). The bibliometric review of female entrepreneurship publications shows three main areas of interests: entrepreneurial profiles of women, gender identity and theoretical conceptualizations of female entrepreneurship and the entrepreneurial process context (Santos et al., 2018). Further review also indicates a connection between female entrepreneurship in developed and developing countries, including crosscountry comparisons and intersectionality of the research field (Poggesi et al., 2016). The gender gap in entrepreneurship can be also observed in women's concentration in certain sectors and their poorer performances; businesses run by women face generally fewer employees, slower sales growth, lower growth ambitions and limited internationalization (Langevang et al., 2015).

There are several theories that explain the gender gap in entrepreneurship. According to the social role theory, people follow certain stereotypes to be socially acceptable, including gender stereotypes and gender roles. Women are stereotyped as staying at home and caring for the family, while men are perceived to work and bring in the income, which in consequence makes the male group more likely to start and run businesses and hinders women's willingness to do so (Rubio-Banón and Esteban-Lloret, 2016).

The institutional theory perceives formal and informal institutional factors as influencing entry decisions (especially access to resources as the result of property rights and the size of state sector) and explaining female engagement in entrepreneurial activity (Estrin and Mickiewicz, 2011). Informal factors seem to be more relevant in explaining female entrepreneurship than the formal factors (Noguera et al., 2015). Stereotypes and patriarchy prevent women from engaging in entrepreneurial activity (Naguib and Jamali, 2015; van Ewijk and Belghiti-Mahut, 2019), while women's economic participation encourages female entrepreneurship (Pathak et al., 2013). Informal institutions have also moderating effects on the strength of formal institutional impact. There is evidence that cultural specificities, such as masculinity, individualism and indulgence weaken the influence of the public expenditure on childcare; this, however, does nothing to foster female entrepreneurship (Gimenez-Jimenez et al., 2020). Although the domestic responsibilities of women are discussed in female entrepreneurship literature, there is no consensus as to whether household duties hinder or encourage the establishment of companies (Alsos et al., 2016).

Female entrepreneurship can be also analyzed from the point of view of occupational choice theory which assumes that an individual can choose to be a wage worker with risk-free salary or an entrepreneur with uncertain entrepreneurial profit (i.e. Kihlstrom and Laffont, 1979; Pardo and Ruiz-Tagle, 2017). The choice is made based on comparing financial and nonfinancial costs and the benefits of both forms of occupations; the decision to become an entrepreneur is made when the benefit of self-employment exceeds the benefits obtained as an employee. These choices are motivated by groups of factors known as the theories of entrepreneurial pull (or opportunity-driven) and recessional push (or necessity-driven) (Krasniqi, 2014; Ng and Fu, 2018; Jafari-Sadeghi, 2020). Pull (opportunity-driven) factors assume that women are attracted by the psychological and social benefits, such as independence, flexibility and job satisfaction (Lawter et al., 2016). Entrepreneurship is as a type of occupation, which allows for a better balance of professional life and family responsibilities (McGowan et al., 2012).

Push (necessity-driven) factors foresee necessity as the main entrepreneurial motivation, women are pushed toward entrepreneurship by frustrations and the lack of professional development they experienced in traditional employment (McGowan et al., 2012), reaching the "glass ceiling" or the predominance of male networks (Humbert and Drew, 2010). Gender stereotypes are another "push" motivational factor for female entrepreneurship (Adom and Anambane, 2020). Negative push factor often become an impulse for women to take a positive step into entrepreneurship (McGowan et al., 2012). Moreover, to understand differences in 
motivations, gender should be analyzed together with other social factors, such as, for example, marital status or parenthood (Humbert and Drew, 2010).

Female entrepreneurship should be seen in the larger socioeconomic context as being a result of many social forces (Bourne, 2010) including country risk score conditions, the presence of women in positions of power, gender labor-force gap, wage gaps (Ribes-Giner et al., 2018), the entrepreneurial eco-system and gender equality (Berger and Kuckertz, 2016). The size of the state sector and discrimination against women reduce female entrepreneurship (Estrin and Mickiewicz, 2011). Among sociocultural factors, the impact of fear of failure and perceived entrepreneurial capabilities (Noguera et al., 2013); female entrepreneurs identity with the terms participative leadership, action-oriented, creativity and problem-solving (Orser et al., 2011); and self-efficacy and fear of failure (Pathak et al., 2013) are confirmed to impact female entrepreneurship.

\section{Female entrepreneurship - research assumptions and results \\ Theoretical assumptions}

The unequal situation for women in the labor market from the neoclassical point of view should be a factor pushing them toward entrepreneurship. Although the question of whether entrepreneurship could be an escape from gender inequality is not a new one, the existing data show a considerable gender gap in entrepreneurial activity worldwide, with significantly more men than women starting or operating new businesses (Langevang et al., 2015). Men are more likely to enter entrepreneurship to create and grow their own businesses (Rubio-Banón and Esteban-Lloret, 2016).

The gender pay gap can be seen as a purely financial factor, resulting from labor market inequality, and as such could encourage women to enter into entrepreneurship. It would be expected that women who cannot get equal pay for work of the same value are more likely to enter into entrepreneurship to gain independence and income equivalent to the value of their work. However, the gender pay gap can also be regarded as a result of social and cultural norms, including the segregation of women in certain occupations and industries, and "preentry" discrimination. If the gender pay gap is a symptom of stereotypes or segmentation, it might not encourage women to enter into entrepreneurship, as women could accept the gender pay gap as part of the social relationship, without trying to become independent by running their own business.

To understand the impact of the gender pay gap on decisions to enter into entrepreneurship, the industry-specific perspective is adopted. Gender segregation by occupation and industry is one of the most important factors that explains the gender pay gap (Karamessini, Ioakimoglou, 2007). On the other hand, as Fitz-Koch et al. (2018) point out, in entrepreneurship, research sector is rarely embraced although the sector, or the industry, though it is often treated as a control variable in empirical studies in other fields. The industry perspective is implemented in Sköld and Tillmar's (2015) research, but it is limited to one country and to female-dominated welfare industries. Another example of implementing the industry perspective is research done by Lawter et al. (2016); however, the pay gap was analyzed not in regard to earnings in total employment but the gender pay gap for entrepreneurs, and the study was conducted in the USA. Sex-based segregation and its impact on entrepreneurship are also considered by Tonoyan et al. (2020); however, they focus on the labor market positions of females as factors impacting the perception of start-up ease.

Depending on the participation of men and women in an industry, they are classified as male-dominated industries, with over $70 \%$ of total employment being men; mixed industries and female-dominated industries, with over $60 \%$ of total employment being women (Karamessini, 2012; Sköld and Tillmar, 2015). In male-dominated industries, women might face entry discrimination and entry barriers; in female-dominated industries, labor market 
IJM

43,9

\section{8}

segmentation is a factor pushing to entry to that industry; while in mixed-industries, there is no barrier and no push to entry for women.

By combining these two perspectives, the theoretical classification of industries can be done with nine types of industries:

(1) with a low gender pay gap and (1) low female participation rate, (2) moderate participation rate and (3) high participation rate;

(2) with a moderate gender pay gap and (4) low female participation rate, (5) moderate female participation rate and (6) high female participation rate;

(3) with a high gender pay gap and (7) low female participation rate, (8) moderate female participation rate and (9) high female participation rate.

Based on this classification, pay gap can be seen as a pushing factor toward entrepreneurship in industries with relatively low barriers of entry or might be treated as a cultural symptom of discrimination and discourage and prevent women from entering into entrepreneurship. This has led us to formulate the following research questions:

$R Q 1$. Does the gender pay gap impact female entrepreneurship in the perspective of industries?

$R Q 2$. What is the nature of the gender pay gap impact on female entrepreneurship, is it a pushing or discouraging factor?

RQ3. Are there significant differences in the impact of the gender pay gap on female entrepreneurship in industries with different levels of gender pay gap?

$R Q 4$. Does the female participation rate in a given industry moderate the impact of gender pay gap on the female entrepreneurship?

RQ5. Are there significant differences in the impact of the gender pay gap on female entrepreneurship in male-dominated and female-dominated industries?

\section{Methods}

To verify the predefined research questions, the empirical research assumed to estimate econometric models that show how the gender pay gap influences female entrepreneurship in different types of industries, meaning that models of female entrepreneurship were estimated separately for each industry. We have chosen industries from 22 European countries which are known from their relative institutional stability. Annual data were extracted from Eurostat databases and covers the years 2009-2018. The industries were chosen based on statistical classification of economic activities in European Community, i.e. "Nomenclature statistique des activités économiques dans la Communauté européenne” (NACE) Rev.2 [1]. Industries were chosen based on the importance of industrial entrepreneurship, sectoral structure and data availability. Table 1 presents the industries and countries the data originated from. The sampled countries allowed for relatively balanced models as they included both countries of higher and lower female entrepreneurial ratios.

The dependent variables of estimated models are the female entrepreneurship rate per industry. Despite the discussion on the essence of entrepreneurship, the narrow definition is accepted, and the female entrepreneurship rate indicates the share of self-employed women in total self-employment by industries. Gender pay gap in industry is accepted in unadjusted form because of data availability in Eurostat as the source of all variables. However, to include the problem of differential of industries, we implemented a set of industry-specific variables which we treated as control ones. Industry-specific control variables, measuring the condition in each industry regarding, are following ones: working time of self-employed women as a measure of 
Industries

Countries analyzed

Manufacturing (NACE C)

Construction (NACE F)

Trade (NACE G)

Accommodation (NACE I)

ICT (NACE J)

Finance (NACE K)

Professional activities (NACE M)

Administration (NACE N)

Education (NACE P)

Health (NACE Q)

Arts (NACE R)

Other (NACE S) Kingdom Kingdom United Kingdom

United Kingdom
Belgium, Czechia, Finland, France, Germany, Hungary, the Netherlands, Poland, Portugal, Slovakia, Slovenia, Spain, Sweden, Switzerland, United

Czechia, Germany, the Netherlands, Poland, Spain, Switzerland, United

Belgium, Bulgaria, Cyprus, Czechia, Denmark, Finland, France, Germany, Hungary, Latvia, Lithuania, the Netherlands, Norway, Poland, Portugal, Romania Slovakia, Slovenia, Spain, Sweden, Switzerland, United Kingdom Belgium, Cyprus, Czechia, Finland, France, Germany, Hungary, the

Netherlands, Poland, Portugal, Slovakia, Slovenia, Spain, Sweden, Switzerland,

Czechia, Germany, the Netherlands, Poland, Spain, Sweden, Switzerland,

Czechia, Germany, Hungary, the Netherlands, Poland, Slovakia, Spain, Switzerland, United Kingdom

Belgium, Bulgaria, Cyprus, Czechia, Denmark, Finland, France, Germany, Hungary, the Netherlands, Norway, Poland, Portugal, Romania Slovakia, Slovenia, Spain, Sweden, Switzerland, United Kingdom

Cyprus, Czechia, Finland, Germany, Hungary, Netherland, Poland, Slovakia, Spain, Sweden, Switzerland, United Kingdom

Cyprus, Czechia, France, Germany, Hungary, Netherland, Poland, Slovakia, Spain, Sweden, Switzerland, United Kingdom

Belgium, Bulgaria, Cyprus, Czechia, Denmark, Finland, France, Germany, Hungary, the Netherlands, Norway, Poland, Portugal, Romania, Slovakia, Slovenia, Spain, Sweden, Switzerland, United Kingdom

Czechia, Finland, France, Germany, the Netherlands, Norway, Poland, Slovenia, Spain, Sweden, Switzerland, United Kingdom

Belgium, Bulgaria, Cyprus, Czechia, Denmark, Finland, France, Germany, Hungary, Lithuania, the Netherlands, Norway, Poland, Portugal, Romania, Slovakia, Slovenia, Spain, Sweden, Switzerland, United Kingdom
Table 1 .

Industries by countries of analyses

work-life balance; female participation rate, showing preentry conditions for women to work in a specific industry and understood as their share in the total employment by industry and industry significance in the economy, measured by its share in gross value added. We also include two country-specific control variables, namely, human capital understood as education level, measured by the share of women with higher education, and unemployment among women. These variables reflect the situation in overall economy of countries. These control variables reflect human capital theory (i.e. education level), discrimination and segregation theories (i.e. pay gap and female participation) and cultural attitude (i.e. working time). The empirical study was divided into several stages. Source of all variables is Eurostat data base and their operationalization is presented in Table 2.

Having established the variables, we followed procedure by estimating regression functions separately for each industry. Due to varying data availability, the final number of observations included in each model was changeable (Column $\mathrm{N}$ in Table 3). In order to avoid autocorrelation and heteroscedasticity problems, we have used the panel corrected standard errors. To determine the appropriate panel regression methods, the Breusch-Pagan test was carried out. Next, if applicable, we used the Hausman test to choose between fixed and random effect models.

Table 3 presents the variance inflation factor (VIF) and squared semi-partial correlation coefficient (Semi $R^{2}$ ) values. Semi $R^{2}$ indicates what share of the variance of dependent variables is explained by a particular independent variable, considering only the relationship 


\begin{tabular}{|c|c|c|c|c|}
\hline \multirow{3}{*}{43,9} & Variable & Abb. & Operationalization & Variable type \\
\hline & $\begin{array}{l}\text { Female entrepreneurship } \\
\text { in industry }\end{array}$ & $\mathrm{FE}$ & $\begin{array}{l}\text { Share of self-employed women } \\
(\%) \text { in total self-employment by industries }\end{array}$ & Industry-specific \\
\hline & Pay gap in industry & PG & $\begin{array}{l}\text { Gender pay gap (\%) in unadjusted form } \\
\text { (structure of earnings survey methodology of } \\
\text { Eurostat) by industries }\end{array}$ & Industry-specific \\
\hline \multirow[t]{4}{*}{50} & Working time in industry & WT & Average number of actual weekly hours of & Industry-specific \\
\hline & $\begin{array}{l}\text { Female participation in } \\
\text { industry }\end{array}$ & FP & $\begin{array}{l}\text { Work per self-employed women by industries } \\
\text { Share of women in total employment in industries }\end{array}$ & Industry-specific \\
\hline & $\begin{array}{l}\text { Industry significance for } \\
\text { the economy }\end{array}$ & VA & $\begin{array}{l}\text { Share of gross value added of industry in total gross } \\
\text { value added in the economy }\end{array}$ & Industry-specific \\
\hline & $\begin{array}{l}\text { Female unemployment } \\
\text { in country }\end{array}$ & FU & $\begin{array}{l}\text { Share of female (15-74) unemployment in the } \\
\text { country }\end{array}$ & Country-specific \\
\hline \multirow{2}{*}{$\begin{array}{l}\text { Table } 2 . \\
\text { Variable } \\
\text { operationalization }\end{array}$} & $\begin{array}{l}\text { Education level in } \\
\text { country }\end{array}$ & $\mathrm{ED}$ & $\begin{array}{l}\text { Share of women (15-64) with higher education in } \\
\text { total number of self-emploved women in the country }\end{array}$ & Country-specific \\
\hline & \multicolumn{4}{|l|}{ Source(s): Own elaboration } \\
\hline
\end{tabular}

between the two. VIF, in turn, is used to detect collinearity. A number of observations $(\mathrm{N})$ are also presented in Table 3 .

As Table 3 indicates, we did not encounter collinearity problems since all of the variables reported VIF values significantly below 10 . However, in effect, in most cases, the semi-partial correlation coefficient was relatively low.

Table 4 summarizes the results of the Breuch-Pagan and Hausman tests. The first test is designed to determine whether a given panel can be estimated using the classical least squares method, i.e. whether there are effects specific to the period or observed unit. A low $p$-value $(<0.05)$ for the Breusch-Pagan test means that panel regression should be applied. The Hausman test, in turn, allows us to determine the nature of observed effects (random or fixed effects). A low $p$-value $(<0.05)$ indicates the use of a model with the fixed effects.

The Breuch-Pagan test reported that for construction, education and arts, the classical least squares method was suitable, while panel regression methods were used for other industries. According to the Hausman test, for trade, accommodation, ICT and professional activities, we have applied panel regression with random effects and for the remaining industries, we applied fixed effects.

\section{Pay gap effect and industry specificity}

To address the research questions, we have classified industries according to the criteria of level of gender pay gap and level of female participation, based on the average levels of these two measures (c.f. Table 5).

As the data show, industries in European countries were very diversified regarding female entrepreneurship, gender pay gap and female participation rate. The female entrepreneurship rate varies between $4.96 \%$ in construction to $72.62 \%$ in other services. Just three industries are characterized by a female entrepreneurship rate higher than $50 \%$; most of them are lower than $40 \%$. The gender pay gap is also very diversified and exists in all industries, and it is unfavorable for women. The lowest one is in construction, where women earn on average $7.85 \%$ less than men. In all other industries, the gender pay gap is higher than $10 \%$, with the highest level in ICT: $21.24 \%$. The most male-dominated industry is construction, with a female participation rate equal to $9.59 \%$. The highest female participation rates are in health $(80.22 \%)$, education $(71.99 \%)$ and other services $(66.78 \%)$. 


\begin{tabular}{|c|c|c|c|c|c|c|c|c|}
\hline & $P G$ & $\mathrm{FU}$ & WT & $\mathrm{ED}$ & $\mathrm{FP}$ & VA & Number of observation & Gender pay \\
\hline \multicolumn{8}{|c|}{ Manufacturing } & \\
\hline & 2.35 & 1.70 & 1.73 & 2.64 & 3.58 & 1.59 & \multirow[t]{2}{*}{150} & \\
\hline Semi $R^{2}$ & 0.57 & 0.41 & 0.42 & 0.62 & 0.72 & 0.37 & & \\
\hline \multicolumn{8}{|c|}{ Construction } & \\
\hline & 2.41 & 1.41 & 1.54 & 2.69 & 2.57 & $\begin{array}{l}2.01 \\
0.50\end{array}$ & \multirow[t]{2}{*}{70} & 51 \\
\hline Semi $R^{2}$ & 0.58 & & 0.35 & & & & & \\
\hline \multicolumn{8}{|l|}{ Trade } & \\
\hline Semi $R^{2}$ & 0.19 & 0.22 & 0.22 & 0.21 & 0.27 & 0.19 & 220 & \\
\hline \multicolumn{8}{|c|}{ Accommodation } & \\
\hline VIF & 1.76 & 1.96 & 1.31 & 1.99 & 1.61 & 2.60 & \multirow[t]{2}{*}{160} & \\
\hline Semi $R^{2}$ & 0.43 & 0.49 & 0.24 & 0.50 & 0.38 & 0.61 & & \\
\hline \multicolumn{8}{|l|}{ ICT } & \\
\hline VIF & 2.87 & 3.27 & 3.12 & 1.88 & 1.29 & 2.21 & \multirow[t]{2}{*}{80} & \\
\hline Semi $R^{2}$ & 0.65 & 0.69 & 0.68 & 0.47 & 0.23 & 0.55 & & \\
\hline \multicolumn{8}{|l|}{ Finance } & \\
\hline & 1.73 & 1.71 & 4.02 & 2.72 & 5.99 & 6.07 & \multirow[t]{2}{*}{90} & \\
\hline Semi $R^{2}$ & 0.42 & 0.42 & 0.75 & 0.63 & 0.83 & 0.84 & & \\
\hline \multicolumn{8}{|c|}{ Professional } & \\
\hline VIF & 1.42 & 1.26 & 1.64 & 2.06 & 1.60 & 1.85 & \multirow[t]{2}{*}{200} & \\
\hline Semi $R^{2}$ & 0.30 & 0.21 & 0.39 & 0.52 & 0.38 & 0.46 & & \\
\hline \multicolumn{8}{|c|}{ Administration } & \\
\hline VIF & 1.37 & 1.38 & 2.66 & 3.78 & 2.24 & 1.37 & \multirow[t]{2}{*}{120} & \\
\hline Semi $R^{2}$ & 0.27 & 0.28 & 0.62 & 0.74 & 0.55 & 0.27 & & \\
\hline \multicolumn{8}{|c|}{ Education } & \\
\hline & 1.10 & 1.42 & 2.45 & 2.54 & 2.27 & 2.12 & \multirow[t]{2}{*}{120} & \\
\hline Semi $R^{2}$ & 0.09 & 0.29 & 0.59 & 0.61 & 0.56 & 0.53 & & \\
\hline \multicolumn{8}{|l|}{ Health } & \\
\hline & 1.37 & 1.16 & 1.78 & 1.63 & 1.83 & 2.59 & \multirow[t]{2}{*}{200} & \\
\hline Semi $R^{2}$ & 0.27 & 0.14 & 0.44 & 0.39 & 0.45 & 0.61 & & \\
\hline \multicolumn{8}{|l|}{ Arts } & \\
\hline VIF & 1.69 & 2.70 & 1.71 & 2.01 & 2.70 & 4.49 & \multirow[t]{2}{*}{120} & \\
\hline Semi $R^{2}$ & 0.41 & 0.63 & 0.41 & 0.50 & 0.63 & 0.78 & & \\
\hline \multicolumn{8}{|l|}{ Other } & \\
\hline VIF & 1.06 & 1.09 & 1.49 & 1.41 & 1.11 & 1.15 & \multirow[t]{3}{*}{210} & \\
\hline Semi $R^{2}$ & 0.06 & 0.09 & 0.33 & 0.29 & 0.10 & 0.13 & & VIF and semi $R^{2}$ \\
\hline \multicolumn{7}{|c|}{ Source(s): Own elaboration } & & \\
\hline
\end{tabular}

We have assumed that the average value of gender pay gap lower than $15 \%$ is low, between 15 and $20 \%$ is moderate and above $20 \%$ is high. Industries with a female participation rate up to $30 \%$ are considered as male-dominated ones with entry barriers for women. Mixed industries are these with a female participation rate between 30 and $60 \%$, while femaledominated industries pushing women to enter are those with a female participation rate higher than $60 \%$. Construction is recognized as an industry with a low gender pay gap and a low female participation rate. Manufacturing is considered as industry with a low female participation rate and a high gender pay gap, while ICT as an industry with low female 


\begin{tabular}{llcc}
\cline { 2 - 3 } IJM & Industry & Breuch-Pagan & Hausman \\
\cline { 2 - 4 } 43,9 & Manufacturing & 0.00 & 0.00 \\
& Construction & 0.20 & $\times$ \\
& Trade & 0.00 & 0.32 \\
& Accommodation & 0.00 & 0.14 \\
$\mathbf{5 2}$ & ICT & 0.01 & 0.78 \\
& Finance & 0.02 & 0.00 \\
& Professional & 0.00 & 0.16 \\
& Administration & 0.00 & 0.00 \\
Table 4. & Education & 0.08 & $\times$ \\
Results of the Breuch - Arts & Health & 0.00 & 0.01 \\
Pagan and & Other & 0.17 & $\times$ \\
Hausman tests & Source(s): Own elaboration & 0.00 & 0.00 \\
\hline
\end{tabular}

participation rate but high gender pay gap. Accommodation is an industry with a moderate participation rate but low pay gap. Administration, professional activities and arts are moderate in both participation rate and pay gap. Trade and finance are characterized by a moderate participation rate and a high gender pay gap. Education bears low pay gap but at the same time high female participation rate. Health and others are characterized by moderate female participation rate and a high pay gap. The basis for our considerations was the statistical significance and value of regression function parameters for gender pay gap in explaining female entrepreneurship rate. These values, together with industry classification, are presented in Table 6.

Analyses of the value and statistical significance of regression functions parameters indicated the gender pay gap influence; we have received strong support for our main assumption that the influence of the gender pay gap on female entrepreneurship is observed at industry level (RQ1), and it is industry-specific impact depending on the level of inequality (RQ2). In some industries, the gender pay gap was statistically insignificant, which means that it has no influence on female entrepreneurship. In other industries, it had a negative impact but with different strength as measured by its value. Results of regression function estimations are presented in Table 7 . All of the models reported acceptable $R^{2}$ (cf. Table 7), which varied from about $53 \%$ in arts (lowest) to $95 \%$ in finance (highest value).

Gender pay gap definitely cannot be considered a pushing factor, i.e. it either bears no statistical significance on the female entrepreneurship rate (accommodation, education, health, ICT, finance, others) or the relationship is negative (construction, manufacturing, arts, professional, trade). Therefore, answering RQ3, we can conclude that it tends to have either a discriminatory character or no meaning at all. When we were considering the significance of gender pay gap in a breakdown of low, moderate and high rates, we found no lasting pattern. In all three categories, we could distinguish industries indicating both discriminatory characters or no significance at all. The moderate pay gap level did feature most discriminatory industries; however, it needs to be underlined that the total number of industries covered here was also the highest. Therefore, we can conclude that our assumptions on the significance of this division found no support (RQ4).

We have also considered whether the significance of the gender pay gap was anyhow dependent on the female participation rate in a particular industry (RQ5). We assumed that the scope of impact might be driven by the entry conditions - the existence or nonexistence of the industry entry barriers. According to the analyses, such dependence can be found among the male-dominated industries and industries will moderate female participation level. However, not all industries under study indicated such relationship. ICT, accommodation and 
Table 5.

Average values and standard deviations of female entrepreneurship, gender pay gap and female participation rate in the analyzed industries and countries 
IJM

43,9

\section{4}

administration reported no statistical significance. Among the female-dominated industries, all of the industries in study reported no significant relation at all.

While we focused on the moderating role of a gender pay gap in pushing or constraining female entrepreneurship in different industries, we have also controlled for other factors. We have found that generally, in industries with low and high female participation rates, the female unemployment rate played a negative role in fostering female entrepreneurship. The female participation rate seems independent of industry specificity as it reported significant positive values among all of the studied industries. Additionally, among the vast majority of industries, the working time has a significant and negative effect on the rate of female entrepreneurship. No general pattern can be observed in the case of industry significance for the economy and education as the factors mostly seen as statistically significant; however, the direction of the impact varies.

\section{Discussion and conclusions}

The influence of the gender pay gap on female entrepreneurship is industry-specific and depends on the internal levels of equality within an industry. In industries with a high level of inequality, measured by a low participation rate and/or a high gender pay gap, in most cases, the gender pay gap is perceived as a symptom of discrimination and it reduces the level of female entrepreneurship. However, we found one example of such an industry where the pay gap level proved insignificant. As long as women are moderately or highly represented in a specific industry, they do not perceive the gender pay gap as a discriminatory factor discouraging them from entrepreneurship. The significance of pay discrimination is reduced once women are highly represented, and thus, the gender pay gap is seen as unimportant.

Our work makes several theoretical contributions to the literature. First, by implementing an industry breakdown, we indicate whether and how industry specificity impacts the dependence between gender pay gap and female entrepreneurship. Based on the literature review conducted, we have seen the need to fill in the gap of the industry-led studies. Our assumptions proved accurate, since important industry-based differences can be observed. Pay gap seems important only among those industries which generally pose a challenge for women's entry (not only as self-employed but also on a payroll) and in industries with moderate female participation and a high pay gap level. Such results prove that women in those industries expect the pay gap to only increase if they start their own companies. Such fear is not met once women's share in the industry's employment increases. In those sectors,

\begin{tabular}{|c|c|c|c|}
\hline & $\begin{array}{l}\text { Low gender pay gap } \\
\text { (up to } 15 \% \text { ) }\end{array}$ & $\begin{array}{l}\text { Moderate gender pay gap } \\
(15-20 \%)\end{array}$ & $\begin{array}{l}\text { High gender pay gap } \\
\text { (more than } 20 \% \text { ) }\end{array}$ \\
\hline $\begin{array}{l}\text { Low FPR (entry } \\
\text { barriers, up to } 30 \% \text { ) }\end{array}$ & $\begin{array}{l}\text { Construction } \\
(\mathrm{b}(\mathrm{PG})=-0.22 * * *)\end{array}$ & $\begin{array}{l}\text { Manufacturing } \\
\left(\mathrm{b}(\mathrm{PG})=-0.26^{* *}\right)\end{array}$ & ICT (b(PG) insignificant) \\
\hline \multirow[t]{3}{*}{$\begin{array}{l}\text { Moderate FPR (no } \\
\text { entry barriers) }\end{array}$} & $\begin{array}{l}\text { Accommodation (b(PG) } \\
\text { insignificant) }\end{array}$ & $\begin{array}{l}\text { Administration (b(PG) } \\
\text { insignificant) }\end{array}$ & Trade $\left(\mathrm{b}(\mathrm{PG})=-0.10^{*}\right)$ \\
\hline & & Arts $(\mathrm{b}(\mathrm{PG})=-0.21 * * *)$ & $\begin{array}{l}\text { Finance (b(PG) } \\
\text { insignificant) }\end{array}$ \\
\hline & & $\begin{array}{l}\text { Professional } \\
(\mathrm{b}(\mathrm{PG})=-0.26 * *)\end{array}$ & \\
\hline \multirow{3}{*}{$\begin{array}{l}\text { High FPR (push-to- } \\
\text { enter, over } 60 \% \text { ) }\end{array}$} & Education (b(PG) & Health (b(PG) & \\
\hline & insignificant) & insignificant) & \\
\hline & & $\begin{array}{l}\text { Others }(\mathrm{b}(\mathrm{PG}) \\
\text { insignificant) }\end{array}$ & \\
\hline \multicolumn{4}{|c|}{ Note(s): $* * * p<0.01 ; * * p<0.05, * p<0.1$} \\
\hline
\end{tabular}

Table 6.

Classification of analyzed industries in European countries and values of regression function parameter of gender pay gap 


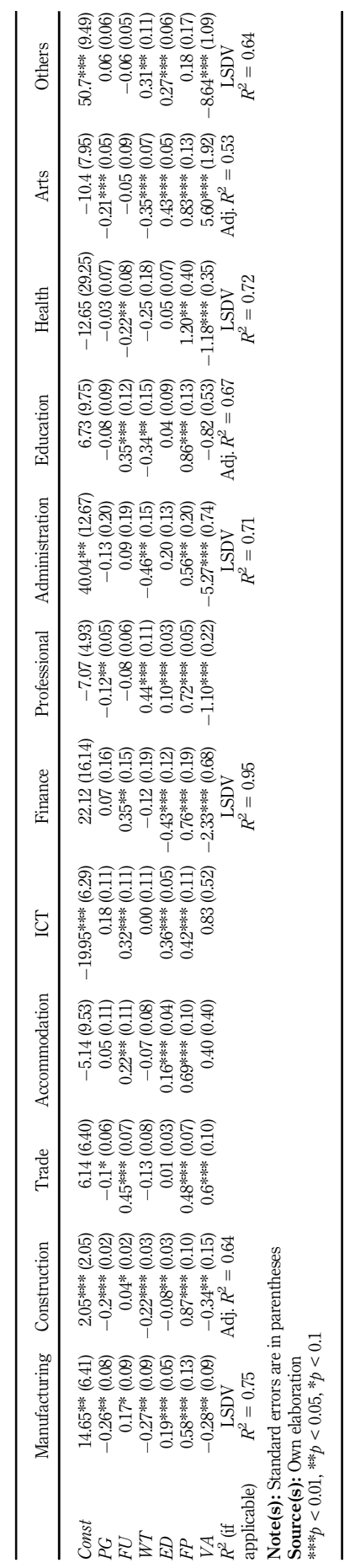

Gender pay

gap

55

Table 7.

Regression function estimations 
IJM

43,9

the pay gap loses its significance, making place for other determinants. This sheds light on the reasons why some studies report the existence of such dependence and some do not.

It is of vital importance to stress that our study has been conducted on a fairly homogenous sample, i.e. the countries included into the study are either members of a regional association (European Union) or remain closely associated with it. All EU Member States agreed to be committed to eliminating the gender inequality and further these core values to become legal standards. The matter can be approached in different ways, including legislated, binding quotas, softer measures or no precise tools at all. For instance, Belgium, Italy Portugal, Germany, Austria and France introduced policies where companies are bound to address gender imbalance in boardrooms of all companies (by imposing quotas). Similar actions were taken in politics. The noncompliance results in penalties. Other Member States (e.g. Denmark, Ireland, Greece, Spain, Luxembourg, the Netherlands, Poland, Slovenia, Finland, Sweden, Switzerland, United Kingdom) introduced such measures for public companies; however, their noncompletion is not accompanied by real penalties. Some of the Member States (e.g. Czechia, Hungary, Slovakia) however decided to restrict their actions to "urging" and "motivating" companies to ensure gender equality, leaving the specifics to companies' discretion. However, the membership requires following common institutional framework and fulfilling common goal, even though the exact tools may differ. Although details on corporate governance or creating entrepreneurial incentives are left in the control of individual countries, in general, they are based on similar assumptions. Therefore, despite the fact that we do encounter regional heterogeneity in terms of degree of institutional engagement and variety of tools used, it is still valid to claim that the countries in the sample can be compared since their Gender Equality Indexes (work category) do not differ much. Among the studied sample, we did not encounter drastic cultural dissonance as to women's roles in business and perception of their abilities, which would make our study biased. This fact needs to be considered if the study is to be replicated on another sample.

\section{Note}

1. To simplify the paper's readability, we use the terms "industry;" however, we would like to stress that notions "industry" and "economic activity" do not match entirely. Delimitation of an industry is a complex task that may be approached from both demand and supply perspectives, and in contemporary economics, the boundaries between industries tend to become blurry, since companies operate in more than one industry at the same time. Economic activity is the supply perspective that refers to the main activities reported by a firm. In the study, the data are based on the economic activities reported by Eurostat; however, at least partially, this methodology matches the context of supply-side industry understanding. Therefore, being aware of the delimitation discrepancies, to simplify the reception, we decided to use the notion "industry".

\section{References}

Adom, K. and Anambane, G. (2020), "Understanding the role of culture and gender stereotypes in women entrepreneurship through the lens of the stereotype threat theory", Journal of Entrepreneurship in Emerging Economies, Vol. 12 No. 1, pp. 100-124, doi: 10.1108/JEEE-072018-0070.

Aidis, R. and Weeks, J. (2016), "Mapping the gendered ecosystem. The evolution of measurement tools for comparative high-impact female entrepreneur development", International Journal of Gender and Entrepreneurship, Vol. 8 No. 4, pp. 330-352, doi: 10.1108/IJGE-12-2015-0044.

Alsos, G.A., Ljunggren, E., Carter, S. and Jørstad, M.O. (2016), "Women, family and entrepreneurship: strategies for managing work-life balance challenges", Academy of Management Annual Meeting Proceedings, Vol. 2016 No. 1, doi: 10.5465/AMBPP.2016.16079abstract. 
Amado, C.A.F., Santos, S.P. and São José, J.M.S. (2018), "Measuring and decomposing the gender pay gap: a new frontier approach", European Journal of Operational Research, Vol. 271, pp. 357-373, doi: 10.1016/j.ejor.2018.05.023.

Arrazola, M. and de Hevia, J. (2016), "The gender wage gap in offered, observed, and reservation wages for Spain”, Feminist Economics, Vol. 22 No. 4, pp. 101-128, doi: 10.1080/13545701.2015. 1135248.

Barnet-Verzat, C. and Wolff, F.-C. (2008), "Gender wage gap and the glass ceiling effect: a firm-level investigation", International Journal of Manpower, Vol. 29 No. 6, pp. 486-502, doi: 10.1108/ 01437720810904185.

Bauder, H. (2001), "Culture in the labor market: segmentation theory and perspectives of place", Progress in Human Geography, Vol. 25 No. 1, pp. 37-52, doi: 10.1191/030913201672119762.

Berger, E.S.C. and Kuckertz, A. (2016), "Female entrepreneurship in startup ecosystems worldwide", Journal of Business Research, Vol. 69, pp. 5163-5168, doi: 10.1016/j.jbusres.2016.04.098.

Blau, F.D. and Kahn, L.M. (2017), “The gender wage gap: extent, trends, and explanations”, Journal of Economic Literature, Vol. 55 No. 3, pp. 789-865, doi: 10.1257/jel.20160995.

Bourne, K.A. (2010), "The paradox of gender equality: an entrepreneurial case study from Sweden”, International Journal of Gender and Entrepreneurship, Vol. 2 No. 1, pp. 10-26, doi: 10.1108/ 17566261011026529 .

Cutillo, A. and Centra, M. (2017), "Gender-based occupational choices and family responsibilities: the gender wage gap in Italy", Feminist Economics, Vol. 23 No. 4, pp. 1-31, doi: 10.1080/13545701. 2017.1285041.

Dawson, Ch., Henley, A. and Latreille, P. (2014), "Individual motives for choosing self-employment in the UK: does region matter?”, Regional Studies, Vol. 48 No. 5, pp. 804-822, doi: 10.1080/00343404. 2012.697140.

Estrin, S. and Mickiewicz, T. (2011), "Institutions and female entrepreneurship", Small Business Econonomics, Vol. 37, pp. 397-415, doi: 10.1007/s11187-011-9373-0.

Ewijk van, A.R. and Belghiti-Mahut, S. (2019), "Context, gender and entrepreneurial intentions. How entrepreneurship education changes the equation", International Journal of Gender and Entrepreneurship, Vol. 11 No. 1, pp. 75-98, doi: 10.1108/IJGE-05-2018-0054.

Fitz-Koch, S., Nordqvist, M., Carter, S. and Hunter, E. (2018), "Entrepreneurship in the agricultural sector: a literature review and future research opportunities", Entrepreneurship Theory and Practice, Vol. 42 No. 1, pp. 129-166, doi: 10.1177/1042258717732958.

Fitzpatrick, D. (2017), "Self-employment dynamics in Australia and the importance of state dependence”, Economic Record, Vol. 93, pp. 144-170, doi: 10.1111/1475-4932.12337.

Gimenez-Jimenez, D., Calabrò, A. and Urbano, D. (2020), "The neglected role of formal and informal institutions in women's entrepreneurship: a multi-level analysis", Journal of International Entrepreneurship, Vol. 18 No. 2, doi: 10.1007/s10843-020-00270-8.

Gradín, C., del Río, C. and Cantó, O. (2010), "Gender wage discrimination and poverty in the EU", Feminist Economics, Vol. 16 No. 2, pp. 73-109, doi: 10.1080/13545701003731831.

Humbert, A.L. and Drew, E. (2010), "Gender, entrepreneurship and motivational factors in an Irish context”, International Journal of Gender and Entrepreneurship, Vol. 2 No. 2, pp. 173-196, doi: 10. 1108/17566261011051026.

Jafari-Sadeghi, V. (2020), "The motivational factors of business venturing: opportunity versus necessity? A gendered perspective on European countries", Journal of Business Research, Vol. 113, pp. 279-289, doi: 10.1016/j.jbusres.2019.09.058.

Jamali, D., Sidani, Y. and Kobeissi, A. (2008), "The gender pay gap revisited: insights from a developing country context”, Gender in Management: An International Journal, Vol. 23 No. 4, pp. 230-246, doi: 10.1108/17542410810878059. 
IJM

43,9

\section{8}

Jennings, J.E., Jennings, P.D. and Sharifian, M. (2016), "Living the dream? Assessing the 'entrepreneurship as emancipation' perspective in a developed region”, Entrepreneurship: Theory and Practice, Vol. 40 No. 1, pp. 81-110, doi: 10.1111/etap.12106.

Karamessini, M. (2012), "Labour market impact of four recessions on women and men in Greece: comparative analysis in a long term perspective”, Social Cohesion and Development, Vol. 7 No. 2 , pp. 93-104, doi: 10.12681/scad.8978.

Karamessini, M. and Ioakimoglou, E. (2007), "Wage determination and the gender pay gap: a feminist political economy analysis and decomposition”, Feminist Economics, Vol. 13 No. 1, pp. 31-66, doi: $10.1080 / 13545700601075088$.

Khoreva, V. (2011), “Gender pay gap and its perceptions", Equality Diversity and Inclusion: An International Journal, Vol. 30 No. 3, pp. 233-248, doi: 10.1108/02610151111124969.

Kihlstrom, R.E. and Laffont, J.-J. (1979), "A general equilibrium entrepreneurial theory of firm formation based on risk aversion", Journal of Political Economy, Vol. 87 No. 4, pp. 719-748, doi: $10.1086 / 260790$.

Kovalenko, M. and Mortelmans, D. (2014), "Does career type matter? Outcomes in traditional and transitional career patterns", Journal of Vocational Behavior, Vol. 85, pp. 238-249, doi: 10.1016/j. jvb.2014.07.003.

Krasniqi, B.A. (2014), "Characteristics of self-employment: a refuge from unemployment or road to entrepreneurship”, Small Enterprise Research, Vol. 21 No. 1, pp. 33-53, doi: 10.1080/13215906. 2014.11082075.

Langevang, T., Gough, K.V., Yankson, P.W.K., Owusu, G. and Osei, R. (2015), "Bounded entrepreneurial vitality: the mixed embeddedness of female entrepreneurship", Economic Geography, Vol. 91 No. 4, pp. 449-473, doi: 10.1111/ecge.12092.

Lawter, L., Rua, T. and Andreassi, J. (2016), "The glass cage: the gender pay gap and self-employment in the United States", New England Journal of Entrepreneurship, Vol. 19 No. 1, pp. 23-38, doi: 10. 1108/NEJE-19-01-2016-B002.

Lips, H.M. (2013), "The gender pay gap: challenging the rationalizations. Perceived equity, discrimination, and the limits of human capital models", Sex Roles, Vol. 68, pp. 169-185, doi: 10.1007/s11199-012-0165-z.

McGowan, P., Redeker, C.L., Cooper, S.Y. and Greenan, K. (2012), "Female entrepreneurship and the management of business and domestic roles: motivations, expectations and realities", Entrepreneurship \& Regional Development, Vol. 24 Nos 1-2, pp. 53-72, doi: 10.1080/08985626. 2012.637351.

Munir Sidani, Y. (2013), "Gaps in female labor participation and pay equity: the impact of cultural variables”, Gender in Management: An International Journal, Vol. 28 No. 7, pp. 424-440, doi: 10. 1108/GM-11-2012-0089.

Naguib, R. and Jamali, D. (2015), "Female entrepreneurship in the UAE: a multi-level integrative lens", Gender in Management: An International Journal, Vol. 30 No. 2, pp. 135-161, doi: 10.1108/GM12-2013-0142.

Ng, K.S. and Fu, P.P. (2018), "Factors driving foreign women entrepreneurship in China", Entrepreneurial Business and Economics Review, Vol. 6 No. 4, pp. 49-69, doi: 10.15678/EBER. 2018.060403.

Noguera, M., Alvarez, C., Merigo, J.M. and Urbano, D. (2015), "Determinants of female entrepreneurship in Spain: an institutional approach", Computational and Mathematical Organization Theory, Vol. 21, pp. 341-355, doi: 10.1007/s10588-015-9186-9.

Noguera, M., Alvarez, C. and Urbano, D. (2013), "Socio-cultural factors and female entrepreneurship", International Entrepreneurship and Management Journal, Vol. 9, pp. 183-197, doi: 10.1007/ s11365-013-0251-x.

Orser, B.J., Elliott, C. and Leck, J. (2011), "Feminist attributes and entrepreneurial identity", Gender in Management: An International Journal, Vol. 26 No. 8, pp. 561-589, doi: 10.1108/17542411111183884. 
Pardo, C. and Ruiz-Tagle, J. (2017), "The dynamic role of specific experience in the selection of selfemployment versus wage-employment”, Oxford Economic Papers, Vol. 69 No. 1, pp. 189-212, doi: 10.1093/oep/gpw047.

Pathak, S., Goltz, S. and Buche, M.W. (2013), "Influences of gendered institutions on women's entry into entrepreneurship", International Journal of Entrepreneurial Behaviour \& Research, Vol. 19 No. 5, pp. 478-502, doi: 10.1108/IJEBR-09-2011-0115.

Poggesi, S., Mari, M. and De Vita, L. (2016), "What's new in female entrepreneurship research? Answers from the literature", International Entrepreneurship and Management Journal, Vol. 12, pp. 735-764, doi: 10.1007/s11365-015-0364-5.

Ravazzini, L. and Chesters, J. (2018), "Inequality and wealth: comparing the gender wealth gap in Switzerland and Australia", Feminist Economics, Vol. 24 No. 4, pp. 83-107, doi: 10.1080/ 13545701.2018.1458202.

Reichborn-Kjennerud, K. and Svare, H. (2014), "Entrepreneurial growth strategies: the female touch", International Journal of Gender and Entrepreneurship, Vol. 6 No. 2, pp. 181-199, doi: 10.1108/ IJGE-04-2013-0043.

Ribes-Giner, G., Moya-Clemente, I., Cervelló-Royo, R. and Perello-Marin, M.R. (2018), "Domestic economic and social conditions empowering female entrepreneurship", Journal of Business Research, Vol. 89, pp. 182-189, doi: 10.1016/j.jbusres.2017.12.005.

Rubio-Banón, A. and Esteban-Lloret, N. (2016), "Cultural factors and gender role in female entrepreneurship”, Suma De Negocios, Vol. 7, pp. 9-17, doi: 10.1016/j.sumneg.2015.12.002.

Santos, G., Marques, C.S. and Ferreira, J.J. (2018), "A look back over the past 40 years of female entrepreneurship: mapping knowledge networks”, Scientometrics, Vol. 115, pp. 953-987, doi: 10. 1007/s11192-018-2705-y.

Sköld, B. and Tillmar, M. (2015), "Resilient gender order in entrepreneurship: the case of Swedish welfare industries", International Journal of Gender and Entrepreneurship, Vol. 7 No. 1, pp. 2-26, doi: 10.1108/IJGE-09-2013-0057.

Tonoyan, V., Strohmeyer, R. and Jennings, J.E. (2020), "Gender gaps in perceived start-up ease: implications of sex-based labor market segregation for entrepreneurship across 22 European countries", Administrative Science Quarterly, Vol. 65 No. 1, pp. 181-225, doi: 10.1177/ 0001839219835867.

Tverdostup, M. and Paas, T. (2017), "Gender-specific human capital: identification and quantifying its wage effects”, International Journal of Manpower, Vol. 38 No. 6, pp. 854-874, doi: 10.1108/IJM-052016-0111.

Xiu, L. and Gunderson, M. (2014), "Glass ceiling or sticky floor? Quantile regression decomposition of the gender pay gap in China”, International Journal of Manpower, Vol. 35 No. 3, pp. 306-326, doi: 10.1108/IJM-01-2012-0017.

\section{Corresponding author}

Katarzyna Mroczek-Dąbrowska can be contacted at: katarzyna.mroczek-dabrowska@ue.poznan.pl

For instructions on how to order reprints of this article, please visit our website:

www.emeraldgrouppublishing.com/licensing/reprints.htm

Or contact us for further details: permissions@emeraldinsight.com 